\title{
Política y educación en Tomás de Aquino*
}

\section{Politics and education in Tomás de Aquino}

Fecha de recepción: 2 de febrero de 2011

Fecha de evaluación: 3 de marzo de 2011

Fecha de aprobación: 21 de junio de 2011

\author{
Alberto Cárdenas Patiño*
}

\section{Resumen}

Como continuador del prolongado proceso constituyente de griegos y romanos, se presenta el mejor régimen político según Tomás de Aquino, el "régimen mixto", en el contexto de su época y de su experiencia comunitaria dominicana. El "régimen mixto" tomasiano se utiliza como visor para observar las evoluciones contemporáneas del régimen mixto colombiano (cacocracia).

Palabras clave: Constitución, politeia, patrios politeia, tiranía, oligarquía, monarquía, aristocracia, democracia, politia, régimen mixto, eupedia, cacopedia, cacocracia, presidencialismo

\section{Abstract}

As a continuation of the long constitutional process of the Greeks and Romans, occurs the best political regime, according to Tomás de Aquino, the "mixed regime" in the context of his time and Dominican community experience. "Mixed regime" is used as a thomasian viewfinder to observe the evolution of the contemporary Colombian mixed regime.

Keywords: Constitution, tyranny, oligarchy, monarchy, aristocracy, democracy, presidential system

\footnotetext{
* Lectio Inauguralis Claustro de Docentes 9 de febrero de 2011. Avance línea: "Actualidad de la filosofía política tomasiana", Grupo Raimundo de Peñafort, cat. B Colciencias.

** Miembro de la Sociedad Internacional Tomás de Aquino y del Comité Editorial de la revista Albertus Magnus. Ex Decano de la Facultad de Filosofía. Representante del Rector General ante el Consejo de la Facultad de Derecho de la Universidad Santo Tomás.
} 


\section{EL MEJOR RÉGIMEN POLÍTICO SEGÚN TOMÁS DE AQUINO}

\subsection{La constitución monárquica centralista}

Según el historiador del constitucionalismo moderno, Maurizio Fioravanti, Tomás de Aquino es "paso decisivo" en la reflexión constitucional medieval (2001: 41). Sus contemporáneos consideraban al Aquinate modernus, es decir atento a los reclamos de la realidad contemporánea y a los modos o maneras propias de su tiempo ( modus hodiernus $=\mathrm{a}$ la manera o modo de hoy = modernus). Tomás, de origen gibelino o imperial, afirmó sus convicciones güelfas o pro-papa cuando tuvo que vivir en carne propia la tiranía de su pariente Federico II Hohenstaufen. Por ello, en la Suma Teológica (I-II, $96,5)$ examina de manera crítica el texto jurídico del Digesto, que afirmaba: "Princeps a legibus solutus" ("el príncipe está liberado de las leyes"). Tomás resueltamente limita el concepto imperialista del derecho romano. Y, en cuanto al tema de si la ley obliga al príncipe, procede distinguiendo la vis coactiva de la ley, que no lo afecta, y la vis directiva, que sí lo obliga. El poder coactivo de la ley no es sino para quienes cumplen por temor, de manera externa. Del príncipe se espera que cumpla voluntariamente, sin temor, lo que la ley prescribe y que él debe hacer cumplir.

A pesar de su opción güelfa, Tomás no confunde el sentido de los dos grandes poderes. Muy joven, comentando Las sentencias, afirma la autonomía de uno y otro en cada campo de acción colectiva:

El poder espiritual y secular proceden del poder divino. El poder secular está subordinado al espiritual en las cuestiones que se refieren a la salvación del alma [...] Sin embargo, se debe más obediencia al poder secular que al espiritual en las cosas que se refieren al bien cívico. En efecto, se dice en Mt. 22: 21: "Dad al César lo que es del César"1.
Persuadido de las bondades del poder secular de los reyes para una situación de crisis concreta, con auténtica stásis (fragmentación partidista y conflictiva), Tomás ensayó una propuesta de constitución monárquica centralista. Su hermano Aymón de Aquino vino del reino de Chipre, a cuyo monarca prestaba vasallaje, a exponerle a Tomás la situación de anarquía e ingobernabilidad en la isla. El Maestro, pensando posiblemente en el paradio mático amigo suyo el rey francés Luis IX, escribió De regno 2 , "ofrecido" al príncipe heredero Hugo II de Lusignan, de sólo 14 años, edad en la que los futuros reyes aún pueden recibir consejos. Se trata de un corto texto de fuerte sabor aristotélicociceroniano-bíblico-agustiniano, encaminado a probar que la monarquía es el mejor régimen si es justo, y el peor si se torna tiránico. En este caso, el pueblo no debe respetar el "pacto" al tirano y tiene derecho a resistirle; eso sí, midiendo fuerzas y sin iniciativas privadas.

El joven Lusignan debía saber qué le esperaba si optaba por la tiranía. Si decidía ser un rey justo, Tomás le explicaba sobre sus tareas: conservar lo que había recibido con el reino (hombres, lugares habitables, recursos necesarios para la vida); si fundaba ciudades, debía elegir lugares apropiados para la buena salud, el sustento, el deleite estético, la seguridad, los centros de estudios, los campos de entrenamiento militar, los mercados, los espacios sagrados, de administración de justicia, de los gremios, de los oficios; proveer para que hubiese lo necesario a disposición de las personas, de acuerdo con la condición y el estado de cada uno. El rey debía gobernar como el buen piloto la nave, que tiene que conservarse ilesa y conducirse al puerto. La sociedad humana debía estar al servicio del fin último de los ciudadanos.

2 De regno, con el complemento de Tolomeo de Lucca, es más conocido como De regimine principum, título idéntico a la obra de Egidio Romano (1247-1316), agustino discípulo de Tomás de Aquino. Según fray Esteban de Lusignan, O.P., historiador de Chipre, el De Regno fue dedicado a su pariente Hugo de Lusignan III, lo cual hace pensar que el opúsculo fue compuesto entre 1267 y 1274. 
El rey debía buscar que la sociedad viviera bien, para lo cual se imponían tres cosas: la unión de la paz, practicar la virtud y suficiente cantidad de lo necesario (bienes corporales).

Para que durase el bien público era necesario: saber cambiar a los responsables de las diversas tareas; disuadir de la maldad mediante leyes, penas y premios; organizar la defensa contra los enemigos exteriores. Para la autarquía económica, preferir el auto-abastecimiento a la importación de productos externos. El frecuente trato con mercaderes, que sólo buscan ganar, daña las costumbres y crea la mentalidad de que todas las cosas son objeto de compraventa, en detrimento de la buena fe y del bien común. Los asuntos mercantiles son también contrarios a los ejercicios militares, pues los hombres de negocios suelen vivir a la sombra gozando, y sus cuerpos se debilitan. Los mercaderes, sin embargo, son necesarios para importar lo que falta y exportar lo que se tiene en exceso. Finalmente, para la paz conviene mucho que los ciudadanos se reúnan menos, pues los frecuentes encuentros suelen brindar ocasión de disensiones y sediciones.

Algunos sostienen que, al enterarse Tomás de la muerte prematura del joven príncipe y con la observación de repetidas tiranías principescas, se desencantó de su entusiasmo monarquista como remedio a cualquier anarquía y dejó de escribir al finalizar el capítulo 8 del L. II... O a lo mejor se convenció de que los príncipes no practicaban la lectura. Él sabía lo que había repetido Juan de Salisbury (1115-1180), refiriéndose al frecuente analfabetismo principesco: "Rex illiteratus est quasi asinus coronatus" ("rey iletrado es como burro coronado"). Si podía ser análoga la incompetencia lectiva del principito, para qué continuar dándole consejos escritos de monarquía justa. El discípulo y biógrafo de Tomás, fray Tolomeo de Lucca, insistió en completar la obra para futuros príncipes con madurez lectiva y reflexiva.

\subsection{Régimen mixto, el mejor régimen político}

Tomás, ya no urgido por la situación alarmante de Chipre, sino en escenario favorable para reflexionar con calma sobre la mejor constitución o mejor politía -y teniendo en cuenta las propuestas políticas de las "autoridades" reconocidas, la personal percepción de la política de su tiempo y su experiencia del régimen participativo de la Orden de Predicadores ${ }^{3}-$, excluye una a una las formas puras (monarquía, aristocracia, democracia) y opta por el régimen mixto, cuyo modelo remoto hay que buscar tanto en la patrios politeia grecoromana (constitución de los padres fundadores) y en el historiador Polibio (200-118 a. C.), como en "el hermoso régimen del pueblo de Israel", "la constitución establecida por la ley divina", cuyos referentes se hallan especialmente en el Éxodo y el Deuteronomio ${ }^{4}$. Esta es la "optima politia, bene commixta" ("la mejor organización política, bien articulada"), en la que "el poder sea de todos, en cuanto a que todos pueden ser elegidos y todos toman parte en la elección", como se explica en la cuestión 105 de la I-II de la Suma Teológica.

Medular amenaza a la optima politía es la seditio, trasunto de la antigua stásis o fractura del régimen que preocupaba a los griegos. En la ST, II-II, q. 42, "De seditione", habla de la especial gravedad de la sedición por oponerse a la "unidad de la multitud, es decir, a la unidad del pueblo, de la ciudad o del reino" (a. 2). La otra gravísima amenaza a la integridad del régimen, conexa con la anterior, es alguna forma de tiranía. Tomás tanto le temía, que parece haber dado su vida por combatirla y afrontarla. Desde Dante Alighieri, en el canto 20 del Purgatorio, en la Divina Comedia, se venía in-

3 Orientación temprana del régimen mixto de los dominicos fue el principio tomado del Corpus iuris civilis de Justiniano, Libro V, T. LIX: "Ut quod omnes similiter tangit, ab omnibus comprobetur", o también: "quod omnes tangit ab omnibus approbetur" ("Lo que a todos toca debe ser aprobado por todos").

4 ST, I-II, 105, 1. 
sistiendo en que el Aquinate no murió de muerte natural en 1274, sino asesinado por el tiránico rey de Sicilia Carlos I de Anjou.

El gran Maestro había hecho saber a Carlos que estaba dispuesto a denunciarlo ante el Concilio Lyon, por lo cual podría perder el trono. Sicilia era principado pontificio. Carlos, hermano del futuro santo el rey Luis IX de Francia, supo que Tomás estaba maltrecho de una caída de caballo y se apresuró a enviarle a su médico personal para que lo asistiera. Como era frecuente entonces (y aun hoy) entre los que ejercían el "arte de curar", el médico del príncipe era experto en venenos eficaces. El historiador tomista Eudaldo Forment ha establecido, tras documentada investigación, que Dante conocía la verdadera causa de la muerte de Tomás (2007: 273-280).

Para referirse al mejor régimen político (asegurado contra la sedición y la tiranía), Tomás, en la celebérrima cuestión 105, a. 1 citada, utiliza otras dos expresiones equivalentes: bona ordinatio principum, optima ordinatio. Sin embargo, será politia (adaptación del griego politeia) el término preferido, cuyo contenido semántico va a fusionar bona y optima ordinatio. Politia a veces aparece como sinónimo de república (1937: 29) para aludir, prima facie, a una combinación práctica muy extendida, dado el deseo generalizado de satisfacer al mayor número de ciudadanos: la oligarquía (plutocracia) y la democracia, combinación que busca un fin común atractivo para los dos extremos desiguales: los ricos y los pobres (Demongeot, 1937: 156). Como este equilibrio es difícil, el poder (potestas) debe ser limitado y "ordenado" por leyes aceptadas por unos y otros. Esta politia no es todavía bene commixta, pues permanece latente la posibilidad de hacer primar algún interés de clase, como ocurre con gran frecuencia.

Tomás, de manera realista, estudia otras posibilidades de integración (Demongeot, 1937: 155): aristocracia-oligarquía; aristocracia-oligarquía- democracia; aristocracia-democracia... Pero las encuentra de difícil realización, especialmente si se quedan en mera yuxtaposición de intereses. La fórmula aristocracia-oligarquía es descartada como de realización casi imposible (Demongeot, 1937: 156), por la incompatibilidad entre virtud y afán de riqueza. En general, considera que son viables aquellas fórmulas en que es practicable la búsqueda de un interés general que satisfaga a todos, lo cual se rompe cuando los ricos se instalan en el poder, porque buscan ante todo hacer valer su codicia, principio de injusticia.

El Aquinate se convence de que la optima politia solamente puede unir formas de poder compatibles, es decir, por naturaleza justas, abrazando todos los intereses en juego (el bien de la comunidad). En De regno 5 examina como injustos los tipos de potestas que solo buscan "su propio provecho": la tiranía (de uno), la oligarquía (de los pocos ricos), la democracia (de la muchedumbre del pueblo bajo opresor). Y halla como justos: la república (multitud no opresiva de vencedores), la aristocracia (minoría virtuosa), reino o monarquía (uno solo, pero virtuoso). Como es notorio, la terminología es oscilante, pues república termina como sinónimo de politia en el sentido de régimen complejo o mixto perfecto; y en la cuestión 105 la democracia se reivindica y pasa a clasificarse como régimen justo y como base de toda la potestas del régimen complejo.

Cada uno de los tres regímenes-tipo considerados justos puede pensarse como el mejor, no en absoluto, sino desde un determinado punto de vista: la monarquía, por su unidad centralizadora y la paz consiguiente; la aristocracia y la monarquía, porque exigen ambas la virtud; la aristocracia, porque supone la elección de los mejores entre los virtuosos (justicia distributiva); la democracia, por el posible concierto de las libertades para alcanzar la tranquilidad pública (Demongeot, 1937:

$5 \quad$ L. I, cap. 1. 
129). Pero ninguno de tales tipos es el mejor desde todo punto de vista, como si fuese autosuficiente, y reclama el complemento de las ventajas de los otros regímenes. Es necesario integrar los tres y formar uno solo, que haga interactivos los aspectos deseables de cada uno.

Se trata de crear una entidad nueva. Alcanzar una transformación de los componentes originarios sin quedarse en la yuxtaposición de instituciones. Las características de cada tipo por separado no subsisten en acto (Demongeot, 1937: 173), sino que se convierten en factores interfuncionales, transmutados por la estructura totalizadora de la única potestas. El régimen mixto auténtico no es el resultado de un compromiso inevitable o conciliación entre clases. No se trata de un pacto entre fuerzas que pueden colisionar. El régimen se superpone a las voluntades divergentes originarias.

El régimen mixto propiamente dicho es un fenómeno tridimensional, un corpus piramidal en el cual se funden la unidad (de origen monárquico), que hace convergentes todas las relaciones y acciones desde el vértice hasta la base; la virtud (de origen aristocrático y monárquico), que cualifica a los agentes de potestas de todos los niveles desde la base hasta la cima; la libertad y la inclusión (de origen democrático), que son derechos de todos los miembros de la sociedad política desde la cima hasta la base. El corpus político no es un frankenstein, armado con partes de distintos cadáveres, sino un verdadero organismo animado por tres tipos de principios solidarios, que actúan como fluidos circulatorios desde la cabeza hasta los pies, utilizando la metáfora repetida de los teóricos medievales. Así, esos principios ya no son separables, sino que se co-implican y compenetran en la arquitectura de la potestas, cuyos agentes colaboran atentos a un bien supraindividual no repartible, pero sí compartible: el bien común colectivo, objeto de la justicia general o armonizadora e integradora de todas las partes e intereses sociales. Con base en esa armonización, quienes ejercen la potestas hacen actos de justicia distributiva o difusiva, según méritos, capacidades, necesidades, de tal manera que no haya excluidos de los beneficios del bien común.

La politia bene commixta deberá consistir en potestas suprema, supraindividual y suprasectorial, fuerza aglutinadora única que impone un velo de desinterés particular a todos los ciudadanos, la cual opera como árbitro final de toda colisión en la búsqueda del "propio provecho", que debe ceder siempre ante las exigencias del bien común. No obstante, siguen latentes los riesgos de tiranía de quien está en el vértice y "preside", cuando este no ha alcanzado estabilidad en la virtud y se deja abrumar por las ventajas de la fortuna, que hacen brotar deseos inmoderados, motores de distintos excesos del poder personal: codicia, soberbia, opresión, depredación, abandono de la justicia ${ }^{6}$. Pero la tiranía no es exclusivamente de uno solo: por razones semejantes a las del tirano individual, pueden darse otras formas, como la tiranía de las aristocracias (los mejores) que se convierte en meritocracia elitista y excluyente, sacrificando el interés general (Demongeot, 1937: 133); como la tiranía de la democracia, cuando la masa puede convertirse en opresora de las minorías y amenazar la unidad y la estabilidad, dada su proclividad a dejarse seducir por los demagogos corruptores y malvados (Demongeot, 1937: 148-149). En general, hay que tener en cuenta que la "virtud perfecta" no es generalizada en el entramado social de la politia.

En síntesis, la mejor constitución del cuerpo social es la que asegura la paz y, por lo mismo, se legitima con el consenso. Para ello, es necesario que no haya excluidos en el ejercicio del poder, lo cual no se logra sino uniendo en la potestas suprema lo más valioso de los regímenes justos, teniendo como criterio calificador la atención primordial al valor de coexistencia bien común, por naturaleza

6 ST, I-II, 105, 1, 2m. 
integrador y armonizador de todo bien particular, sin absorber o negar los proyectos de cada uno, pues la persona no se debe al todo social según todo lo suyo ${ }^{7}$. Tiene una esfera de libertad y privacidad que no puede ser invadida por ningún poder.

En la politia bene commixta, la potestas debe ser de todos. El poder debe ser del pueblo en su totalidad (que abarca todas las clases sociales) y los elegidos para presidir o para actuar colegiadamente, como "varones sabios y nobles" (Ios más aptos) ${ }^{8}$, deben ser elegidos de entre el pueblo y por todo el pueblo. Se exige, además, que quien preside la totalidad social no sea un extranjero o que sirva a intereses extranjeros, como en los modelos herodianos, porque "tienen poco afecto al pueblo y cuidan poco de su bienestar", así los elementos aristocrático y democrático sean de base popular. Si la unidad, propósito primordial de quien preside, sirve a intereses ajenos, se desvirtúa toda la pirámide y puede dislocarse o convertirse en un aparato de opresión global ${ }^{9}$.

El Aquinate, por otra parte, no recomienda los mandatos vitalicios o prolongados de los gobernantes, así estos parezcan virtuosos. Escribe en el Comentario a la política: "Sería temible [...] Como la fuerza corporal se debilita con la vejez, así las más de las veces se debilita la fuerza de la mente" ${ }^{\prime 10}$. Su discípulo Tolomeo de Lucca, O.P., historiador y filósofo político, quien quiso completar el De regno, reforzará la doctrina, recomendando el cambio periódico:

Así no se hacen insolentes con la permanencia en el cargo, y se hacen más moderados.

No es verdad que se destruye la república con el cambio de poderes, si se eligen magistrados idóneos [...] Además, no hay peligro alguno, ya que han de

\footnotetext{
ST, I-II, 24, 4, 3m. / II-II, 65, 1.

8 ST, I-II, 105, 1.

9 ST, I-II, 105, 1, 2m.

10 Com. Pol., II, lect. 14, 189.
}

juzgar según las leyes establecidas, a las cuales están sujetos por juramento"1.

\subsection{Régimen mixto, virtud y educación}

Para asegurar el funcionamiento eficiente y eficaz de la politia bene commixta, la virtud debe ser generalizada, debe modelar el carácter de todos los ciudadanos. ¿Y qué es la virtud? Es la fuerza estable y activa (hábito operativo) del talante personal beneficiente, adquirido por la opción constante hacia la vida humana "buena", y favorecido por el medio familiar y social (Bourdieu, 2010: 86) ${ }^{12}$. El talante o carácter virtuoso integra el desarrollo de la inteligencia, el equilibrio personal y la convivencia armoniosa. Tomás pasa revista a 53 virtudes como máximos de perfección humana, pero se atiene a los mínimos para la realización personal, social y política del "hombre en cuanto hombre": las ocho virtudes de la tradición greco-romana ya cristianizadas: a. los hábitos del entendimiento teórico: saber pensar y comunicar (inteligencia), saber relacionar las causas próximas (ciencia), cultivar la comprensión de totalidad (sabiduría); b. Ios hábitos del entendimiento práctico: saber elegir y obrar en situación, subordinando medios valiosos a fines valiosos (prudencia) y saber hacer o transformar (arte), y c. los tres hábitos del saber vivir y del convivir: el equilibrio en la búsqueda del placer (temperancia), la capacidad de superar temores y de resistir en el bien (fortaleza), y la voluntad constante de respetar las exigencias de la alteridad o de la relación intersubjetiva (justicia).

Si los ciudadanos son por lo general virtuosos, no abundarán ni los tontos irracionales ni los idiotas morales. Tomás tiene un "tratado" no sistemático de tonto-logía, es decir, de arquetipos de novirtuosos, así no alcancen el estatus de viciosos. El hombre virtuoso, miembro activo de la optima politia, no será abrumado o desbordado por las

11 De regno o De regimine principum, L. IV, caps. VII-VIII.

12 Compárese con la noción de "habitus" de Pierre Bourdieu, influido por la tradición tomista. 
ventajas y oportunidades de la fortuna, de tal manera que caiga en la soberbia; no se moverá por la codicia, que lo impulsará a acumular sin medida (pleonexia) y a abandonar la justicia, convirtiéndose en depredador; no será fácil de engatusar por los muchos protervos; su consentimiento será lúcido y espontáneo, no constringido por el temor ${ }^{13}$; será capaz de entrar en rebelión contra las "concordias" impuestas por la fuerza; vigilará los síntomas de tiranía y se preparará para resistir a la opresión... ${ }^{14}$. Un pueblo virtuoso garantizará el fundamento de la elegibilidad generalizada: abundarán los "mejores", aptos para ser elegidos, y las libertades electoras gozarán de razones valiosas para decidir.

Los electores deberán tener en cuenta que la riqueza es un fundamento malo e injusto para un régimen político (Demongeot, 1937: 77, 171). No puede ser criterio de elegibilidad, pues el criterio básico válido es la virtud y la capacidad. Por el riesgo de que la riqueza se convierta en motivación para ejercer la potestas, hay que evitar escoger a los ricos (o menos ricos) codiciosos o avarientos y a los pobres avariciosos. Si los elegibles son establemente virtuosos, así sean ricos, acomodados o pobres, preferirán servir al bien común y no aprovecharlo para acrecentar la riqueza o para redimirse de la inopia.

Uno de los primeros tomistas, el ya mencionado fray Tolomeo de Lucca, O.P., se preguntaba si los pobres o los ricos debían ser elegidos para gobernar, y respondía que, con unos u otros, se corría el riesgo de elegir "corruptores de la república" si no se atendía a su virtud, pues podían comportarse "como sanguijuelas que chupan la sangre de la ciudad, como dice el libro de los Proverbios (30: 15): 'la sanguijuela tiene dos hijas que dicen: dame, dame'. Porque su principal intención es el extorsionar con dinero [...]". En cuanto a los po-

\footnotetext{
13 ST, II-II, 19, 1.

14 De regno, L. I, cap. VI.
}

bres, pensaba fray Tolomeo, es preciso distinguir el tipo de pobreza que los afecta:

\begin{abstract}
La voluntaria o la impuesta [...] La primera no daña un régimen, sino sólo la impuesta; pues quien es pobre en esta forma, rara vez o nunca gobernará bien, porque tratará de saciar su apetito [...] El fin de la pobreza voluntaria es el bien honesto, a lo que inclina la virtud. En cambio, el fin de la pobreza impuesta es la propia utilidad, a la que se inclina la codicia. Por tanto, quienes tienen tal ansia por su pobreza, actúan para llenarse el estómago y la bolsa [...] El apetito de quien no tiene riquezas libremente sino de manera impuesta, siempre tenderá a adquirirlas [...] La naturaleza lo impelirá con el apetito a ellas, para llenar el vacío que no puede soportar. Por lo mismo será muy difícil evitar que se lance de una $u$ otra forma a conseguir riquezas. Por tal motivo es peligroso para la república que se nombre cónsul o juez a un hombre pobre, como dice el Filósofo, a no ser que él acepte su pobreza con gusto $[. . .]^{\prime \prime 15}$.
\end{abstract}

Lo cual parece insólito.

Fray Tolomeo, lector de la Suma teológica, había aprendido que las sanguijuelas del poder son corruptoras de la república o peligrosas, porque así como las virtudes están conexas, se reclaman y estructuran en plexo, de tal manera que cada una favorece el desarrollo de las demás y viceversa, de igual modo ocurre con los hábitos operativos viciosos (contra-virtudes): cada uno es causa del otro, empezando por la codicia, que se abre de manera natural y exigitiva a la soberbia o vanagloria, y luego a la envidia, la ira, la gula, la lujuria, la pereza... ${ }^{16}$. O al revés, empezando por la pereza o la lujuria... Un rico avariento o un pobre codicioso, como gobernantes, definen la orientación de la república según su plexo de preferencias interconexas: la prepotencia, la exclusión de los mejores, la agresividad y violencia sistemáticas,

15 De reg. Princ., L. IV, caps. XV, XX.

16 ST, I-II, 84, 1-4. 
las comilonas celebratorias, las orgías, la incuria y el abandono...

Y un vicio lleva a otro en cadena: "Abyssus abyssum invocat", un abismo llama a otro abismo, como repetían los medievales, citando el Salmo 42:7... De ahí el origen del carácter corrupto o vicioso, tan connatural a gobernantes y políticos de talante plutomaníaco. Frente a este carácter, sin duda que el progreso humano exige el carácter ético, estructurado por el plexo virtuoso, como condición de permanencia del homo humanus, réplica del homo barbarus. Sobre el carácter ético escribía, a comienzos del siglo XX, el tomista Cardenal Mercier:

El carácter es una voluntad tallada por los hábitos virtuosos y templada para obrar con firmeza y con regularidad: no como la rama que se balancea al menor soplo externo, sino como el roble que se yergue derecho e inconmovible sobre sus fuertes raíces (Caro, 1974: 103).

Para que todos los agentes de la politia bene commixta alcancen el estado de virtud, que es el de hombre perfecto -alejado del estado vicioso que suponen los regímenes "injustos"-, es necesario un proceso educativo que los guíe y los eleve gradualmente, desde el seno mismo del útero espiritual que es la familia hasta llegar a la mayoría de edad, cuando se supone que estarán aptos para hacerse cargo de sí mismos, de su vida económica (oikonomica) y de sus responsabilidades sociales y políticas. Pero no cualquier educación eleva en la adquisición de las virtudes, especialmente en las de convivencia, a no ser que se trate de una buena educación (que evita la discordancia entre las buenas palabras y las malas obras ${ }^{17}$ ), orientada paso a paso a formar en la libertad perfectiva (de calidad), no en la caprichosa libertad de indiferencia.

Existe una mala educación que opera como sugestión al mal, especialmente a través del ejemplo

17 Com Eth. X, lect. 1. / ST, I-II, 34, 1. personal y colectivo ${ }^{18}$. Tomás sabía, por el contacto con su co-hermano helenista fray Guillermo de Moerbeke, O.P. (1215-1286), arzobispo de Corinto, que los griegos distinguían entre eu-paideusia o eu-pedia (buena educación) y caco-pedia (mala educación). Los griegos oponían eu= bueno, o bien en todos los sentidos, y kakós = malo, sucio, sórdido, malévolo, miserable, en cuanto resultados de la kakía = disposición viciosa, malicia, vicio, malignidad, infamia. Llama la atención que el campo semántico de kakós, en cualquier diccionario griego, reúne más de 70 significantes. Lo cual indica que la mentalidad helénica alertaba contra la presencia cotidiana del multiforme mal social.

Si la cacopedia' ${ }^{19}$ se generaliza, su fruto será la abundancia de protervos (perversos), sujetos agentes de cacocracia, negación del principio aristocrático que estructura el funcionamiento de la pirámide del régimen mixto. La paideia griega era auténtica eupedia para formar en la kalokagathía, el ideal de la perfecta personalidad humana, que, frente al hombre bárbaro, reunía la nobleza o belleza espiritual (kalós) y (kai), la bondad (agathós) ${ }^{20}$, como integración de todas las virtudes, no corrompida ni por la riqueza ni por el poderío, como señalaba Aristóteles (Abbagnano, 2001). La kalokagathía fue recogida por los romanos en su definición de los deberes del jurisprudente ideal: "honeste vivere, neminem laedere, suum cuique tribuere" ("vivir honestamente, no dañar a nadie, dar a cada uno lo suyo"). Ambas tradiciones fueron asumidas por el Aquinate en su definición de educación como proceso de "conducción y promoción al estado perfecto de hombre en cuanto hombre, que es el estado de virtud"21. Auténtica eu-pedia, que, sin duda, Tomás relacionaba conscientemente con los

18 ST, I-II, 81, prol.

19 Cacopedia se usa aquí en su sentido etimológico de educación perversa y deforme, no con la aplicación que hace Umberto Eco en Segundo diario mínimo, en el contexto de la patafísica rabelesiana.

20 Kalós = hermoso, noble, excelente, perfecto; $k a i=y$, también, además; agathós = bueno, recto.

21 Com. Sent., dist. 26, q. 1, a. 1. 
términos griegos kalokagathía y andragathía, cuyo alcance semántico conocía bien ${ }^{22}$. Contaba con la asesoría segura de su experto traductor del griego, el ya mencionado fray Guillermo.

\subsection{Suerte posterior del régimen mixto tomista}

El modelo de régimen mixto de Tomás va a tener fortuna después y será repensado de manera directa en otros procesos de reestructuración constitucional en los siglos siguientes. Es un hecho que la tradición de la Orden de Predicadores - a pesar de que muchos de sus miembros fueron tutores de príncipes o consejeros y confesores de monarcas- mantuvo el paradigma del régimen mixto como propuesta de la filosofía política institucional, que no deja de influir en las actuaciones públicas de destacados dominicos en distintas épocas. En el siglo XV, por ejemplo, va a inspirar el Tratado sobre el régimen de la ciudad de Florencia, del combativo reformador dominico Fra Girolamo Savonarola, O.P. (1452-1498) ${ }^{23}$, enviado a la hoguera por denunciar el régimen tiránico de Ios Borgia. A mediados del siglo XVI, fray Bartolomé de Las Casas, O.P., en varios textos, reclama la intervención del pueblo para equilibrar el poder monárquico y su aparato aristocrático (1978). A comienzos del siglo XVII, el genial perseguido Fra Tommaso Campanella, O.P. (1568-1639), antes de redactar su utopía La ciudad del sol, escribió los Aforismos políticos, una especie de analítica de las ventajas y de los vicios de los distintos regímenes, y alertó sobre las dificultades del régimen republicano (mixto), dado que el demos resulta incapaz de intervenir con lucidez en la construcción del bien común. Ya en pleno siglo XIX, el gran liberal fray Enrique Domingo Lacordaire, O.P., elogia el régimen mixto de la Orden (Lacordaire, 1998: 52-53; 1998b: 121) y de la filosofía tomista, cuyos

\footnotetext{
22 Tomás de Aquino no desconocía la terminología aristotélica. En el Com. Pol. se refiere al kalocagathos en el sentido de virtuoso y a la andragathia o bondad viril (II, 14, 188 i/ 189).

23 Diccionario de Filósofos de Gallarate, Rioduero, Madrid, 1986.
}

componentes coinciden con la evolución de las instituciones de la Revolución Francesa.

Pero la optima politia bene commixta no quedó exclusivamente en preocupación de los maestros dominicos y de varios jesuitas, sino que fue influyendo en instituciones, filósofos, políticos y hombres públicos, dejando huella en el constitucionalismo moderno y contemporáneo. Hacia 1968, el constitucionalista Leopoldo Uprimny, inspirado en el historiador de la política George Sabine, hizo en la Universidad Santo Tomás (Bogotá) -a tres años de su restauración- una disertación acerca de la teoría tomista del régimen mixto y su influjo en el origen del constitucionalismo norteamericano, modelo de casi todos los regímenes políticos presidenciales (de componente monárquico mitigado) y presidencialistas (de componente monárquico hipertrófico $)^{24}$. Según Uprimny, el sobrio y preciso discurso de Tomás sobre la optima politia, bene commixta (cuestión 105, I-II, ST) funcionó como bisagra entre la teoría política del mundo antiguo y la del mundo medieval, y luego entre esta y el constitucionalismo moderno. El puente posterior hay que buscarlo en John Locke, discípulo del "sesudo" Hooker, traductor de la Suma teológica, hasta llegar a Thomas Jefferson y la Constitución de Filadelfia. Uprimny sugería que si a los regímenes presidenciales se les denomina así es porque ya había una insinuación de cambio terminológico en el lenguaje tomasiano, que introduce los significantes "presidir" y "presidente" para aludir a la función del princeps (Uprimny, 1968: 11-40).

24 La debilidad de las tradiciones aristocrático-democráticas favorece la opción presidencialista (monarquismo encubierto: castrismo, chavismo, uribismo, evismo...). Y este modelo impulsa a quien preside, si no es virtuoso, en palabras del Aquinate, a procurar "multiplicar carros, caballos y mujeres e inmensas riquezas: el deseo de todo eso inclina a la tiranía y al abandono de la justicia" (ST., 105, 1, 2m.). De ahí a preferir el modelo Otoño del patriarca (sentarse sobre bayonetas) no hay sino un paso, como ha ocurrido con frecuencia en América Latina, tierra de dictadores perpetuos. 
En 1981, en Raíces escolásticas de la Constitución norteamericana ${ }^{25}$, O. Carlos Stoetzer, de la Fordham University de New York, señalaba los elementos doctrinales básicos de la comprensión constitucional tomista (estrechamente relacionada con la democracia representativa de los dominicos) y precisaba su destino en el desarrollo del constitucionalismo posterior, con énfasis en la consolidación de las instituciones inglesas y norteamericanas, mostrando los nudos de conexión más importantes de la red de influencias.

\begin{abstract}
Con Santo Tomás -escribía Stoetzer-, llegamos al apogeo de la Edad Media. Incorporando el pensamiento de Aristóteles a la Escolástica y ampliando el concepto agustiniano del hombre social, Santo Tomás calificó a la naturaleza humana como animal político, social, moral y racional. Reflejando un periodo histórico muy superior a los de los carolingios y visigodos, el doctor angélico observó la disolución del sistema feudal, la aparición del estado territorial y nacional, y, con la muerte del emperador Federico II, la decadencia del Sacro Imperio Romano. Vio en su propia orden dominicana un ejemplo de democracia representativa: los representantes que ejercían la autoridad suprema eran elegidos por los comités locales. El modelo de la orden le servía para desarrollar una doctrina política que todavía hoy tiene vigencia y nada de anticuado, oscurantista 0 antiliberal. [...] El punto de partida de Santo Tomás fue la soberanía popular como fuente y origen de todo buen gobierno. La idolatría del Estado, tan común en la antigüedad como en la época moderna, tanto en Platón como en Hegel, no era parte de la filosofía medieval y mucho menos en Santo Tomás. Para el doctor angélico el pueblo era una comunidad política autónoma, y, aceptando la definición agustiniana de q ue una comunidad política era una "multitud unida por consentimiento jurídico", Ilegó a la forma mixta de gobierno con sus
\end{abstract}

25 Ponencia de 1981, en las XV Jornadas del Seminario Internacional de Estudios Americanos, en Buenos Aires, publicada en el No. 77 de Franciscanum, revista de la Universidad San Buenaventura, Bogotá. elementos monárquicos, aristocráticos y democráticos. No obstante la forma mixta, en este régimen todos participaban, porque todos podían ser elegidos a gobernar y porque los gobernantes eran seleccionados por todos [...]" (Stoetzer, 1981: 156-157).

Renglones después, añade Stoetzer:

Todo gobierno, según Santo Tomás, estaba basado en un pacto, y por lo tanto revocable si el príncipe actuaba en contra del derecho natural. Siguiendo la tradición cristiana, era tirano el príncipe que ignoraba el bien común; el príncipe no era legibus solutus, sino que tenía el deber de obedecer las leyes, y el pueblo podía resistir al tirano, pues tal resistencia era legítima si la causa era justa y si la justicia estaba fundada en el bien común, que era la finalidad de toda sociedad. Sin embargo lo que era justo, según Santo Tomás, variaba de acuerdo con las diferentes situaciones del hombre y de su condición, y si bien el hombre tenía iguales derechos naturales, "cierto orden jerárquico era esencial para su coexistencia social", y este orden debía estar basado en la existente distribución de desigualdades y aptitudes, lo cual implicaba que la democracia, si no se quería que resultara en un caos de mediocridad e incompetencia, tenía que regirse por el principio aristocrático, el gobierno de los mejores (Stoetzer, 1981: 158).

\section{Precisaba párrafos atrás Stoetzer:}

Ahora bien, la universalidad, la justicia, la dignidad humana [...] son principios cristianos [...] Los principios de la soberanía popular, del régimen mixto, constitucional o moderado [...] son de raíz medieval, de modo que, tanto los influjos del puritanismo inglés del siglo XVII como del racionalismo francés del siglo XVIII, representan tan sólo la base intelectual moderna de la Constitución, y por cierto, la mayormente conocida. Hemos señalado que ciertos principios lockeanos tenían un fondo medieval, y en el caso de Montesquieu, su vinculación con la Edad Media es evidente. Hacemos, pues, hincapié en que el do- 
cumento constitucional norteamericano se remonta a orígenes mucho más antiguos que los de los siglos XVII y XVIII. Sabemos, en líneas generales, que Santo Tomás influyó a través del cardenal Bellarmino en Thomas Jefferson y James Wilson; que el mismo Santo Tomás tuvo influencia en Richard Hooker, quien a su vez influyó en Locke; que Santo Tomás tuvo influencia en otros pensadores escolásticos que a su vez tuvieron un impacto intelectual en los Whigs del siglo XVIII, quienes a su vez influyeron en varios de los signatarios de la Declaración de Independencia de Estados Unidos; que Santo Tomás, a través de Francisco de Vitoria y de Francisco Suárez influyó, por un lado, en Edmund Burke, padre del pensamiento conservador moderno [...], y por el otro, también a través de Vitoria y Suárez en Sidney, quien a su vez tuvo un eco intelectual en otros signatarios de la citada Declaración de Independencia. Todo esto es muy lógico, si tenemos en mente la gran repercusión que tuvo el influjo de toda la Escuela Española de la Segunda Escolástica en toda la escuela protestante del derecho natural (Grocio, Pufendorf, Thomasio, Althusio, Wolff). Finalmente, no hay que ignorar el gran impacto del jurista inglés Sir John Fortescue en los Whigs de 1688 y que a través de estos llegó también a varios de los signatarios de la Declaración de Independencia [...] (Stoetzer, 1981: 148-149).

Por su parte, en 2006, el constitucionalista español Enrique Álvarez Conde explica, en su Curso de derecho constitucional:

La Escolástica española no hizo sino actualizar las tesis tomistas. Las cortapisas al poder absoluto de los monarcas, tan en boga en los siglos XVI y XVII, eran en realidad una defensa indirecta del régimen político "mixto" propugnado por Aquino que, con el tiempo, se convertirá en el paradigma teórico de la moderna democracia constitucional y permitirá a las democracias cristianas reivindicar para el santo el patrocinio del contemporáneo Estado de derecho (Álvarez, 2006: 40).
Tal paradigma opera como modelo transnacional, que influye no solamente en el surgimiento y maduración de las democracias europeas y norteamericana, sino que llega a los orígenes mismos de las nuevas repúblicas ex coloniales de comienzos del siglo XIX. En vísperas de la independencia de la Nueva Granada, en época de reclamos criollos, el régimen tomasiano se esgrimía como instrumento de crítica política. En el punto 59 de la Defensa de don Antonio Nariño ante la Real Audiencia, en 1795, el precursor y su abogado defensor, el doctor José Antonio Ricaurte y Rigueyro, afirmaban que, comparada la teoría del régimen mixto de Tomás con las máximas de los Derechos del Hombre, aquella resultaba más decisiva, más clara, mucho más fuerte, desde el punto de vista de la realidad neogranadina.

\section{RÉGIMEN MIXTO TOMISTA Y PRÁCTICAS COLOMBIANAS CONTEMPORÁNEAS}

Atendamos hoy la insinuación de don Antonio Nariño y de su abogado, y miremos con ojos tomasianos los usos políticos colombianos. Aunque nuestros referentes políticos contemporáneos se distancian de los que intentaba asumir Tomás de Aquino en el siglo XIII, su teoría del régimen mixto -por funcionar como paradigma de la democracia constitucional occidental- sirve aún como un adecuado visor para observar nuestras prácticas, especialmente porque la estructura esencial de aquel (más o menos desvirtuada) se trasladó desde las primeras constituciones a la de 1886 y a la de 1991, y seguramente sin que lo recordaran o lo supieran los miembros de la Asamblea Nacional Constituyente. Usamos instrumentos asimilados por la cultura sin conocer su marca y menos su origen. Sin embargo, un ex constituyente como el doctor Álvaro Echeverri Uruburu parece recordarlo de manera diluida, con énfasis en dos tomistas jesuitas, en una página de su Teoría constitucional y ciencia política (Echeverri, 2002: 264). 


\subsection{Régimen mixto colombiano y cacocracia}

No obstante, hay que afirmar que nuestro régimen mixto colombiano, aunque teóricamente se inspira en el triángulo tomista, que funde principios de los regímenes justos, en la práctica -por nuestras viciosas raíces pre-republicanas y republicanas- se ajusta más al régimen mixto que articula principios monárquicos con oligárquicos (plutocráticos) y democráticos (con evidentes reiteraciones oclocráticas por manipulación demagógica). Y ha subsistido una tácita alianza interactiva entre lo real (monárquico, que traspasó la historia coIonial y se conservó hasta hoy, junto con pavos reales, riales [monedas], caminos reales, reinosos, reinas de belleza, reyes vallenatos...) y los intereses oligárquicos, sin presencia aristocrática auténtica (así se aleguen apellidos). El principio aristocrático tomista que debe actuar como savia en todos los niveles del corpus político no parece haber arraigado como criterio ni para elegir, ni para ser elegido: reiteradamente, no se elige a los mejores, ni a los buenos, ni las mayorías de electores (en país de abstención) son los mejores de la voluntad general. Lo más frecuente es que estos (en tácita connaturalidad) voten por quienes tienen la impronta de la kakía, oculta bajo las sonrientes y flamantes fotografías de la publicidad de campaña y de los tarjetones de votación (todos en actitud heroica y aun hierática, y algunos en pose de santidad, como la candidata presidencial revirginizada que "ascendía a los cielos" en la publicidad televisiva).

El régimen mixto colombiano parece fundarse, desde su origen, en el pésimo basamento de la riqueza como criterio electivo y como propósito de los elegidos (sanguijuelas los clientes electores y sanguijuelas los otros), en su mayoría pobres no virtuosos, afanados por superar su indigencia, o ricos no virtuosos, buscando enriquecerse más y más. Cuando el fundamento del régimen no es la virtud -resorte del honeste vivere-, los agentes políticos están dispuestos a activar todo género de tiranía o forma de injusticia opresiva, desde quien preside el ejercicio de la potestas hasta quienes participan por delegación o por competencia colegiada y quienes actúan por medio del voto en elecciones, plebiscitos, referendos...

El régimen presidencialista colombiano lleva en su seno factores de injusticia que permiten calificarlo de cacocrático, dada la preponderancia en el aparato de poder, no de los buenos o de los mejores, sino de los "malos" o de los "peores", que no buscan el bien común sino mantener las ventajas del heredado sistema clientelista de servicios mutuos: los de arriba patrocinan a los de abajo a cambio de adhesión ciega y de servicios electorales. En la década de los años treinta del siglo XX, el periodista polemista dominico fray Francisco Mora Díaz, O.P., precursor de la restauración de la USTA, consciente de las exigencias del régimen mixto tomista y observador de la politiquería nacional (desde el poder y por el poder), se convenció de que nuestro régimen patrio merecía denominarse peorcracia (Mora, 1939: 159).

Y algo que tiende a agravar los efectos peorcráticos es la tendencia a perpetuarse en el poder por parte de los operadores del régimen o del partidismo político reductivo (partidocracia de dos partidos, o de partido único, o de partido pantagruélico engullidor, o de partido único que juega a la fragmentación para simular pluralismo...), bloqueando el relevo natural (o participación) exigido por el auténtico régimen mixto. Apetito de sanguijuelas cebadas. Así, en el seno del régimen, en los tres niveles de la pirámide, sin que haya usurpación formal ${ }^{26}$, va echando raíces alguna forma de tiranía que inficiona todos los órganos del poder... La clase política colombiana considera natural perpetuarse en el poder, como resultado de la arraigada convicción de sus representantes (de

26 El Aquinate distinguía dos formas básicas de tiranía: por ejercicio o por usurpación. 
hinchada autoestima) de que la democracia es una mascarada y de que la verdad práctica política es la del dicho atribuido a don Marco Fidel Suárez: "Ve más un águila sola que un ejército de lechuzas". Por ello, el poder tiende a convertirse en vitalicio en cabeza de los reelegidos de todas las elecciones o de los "delfines", que lo consideran hereditario. Unos se consideran águilas por sus exitosas taimería y viveza (presunta inteligencia); los otros se estiman aquilinos por razones genéticas, hijos de águilas bien hormonadas (como se consideraba a sí mismo el ex presidente Turbay, aunque sus aguiluchos han sido de corto vuelo). Todos bloquean la circulación y el relevo de inteligencias y voluntades que supone la dinámica de la auténtica optima politia.

El filósofo político Michelangelo Bovero, sucesor de Bobbio, se refiere también a la peorcracia como corrupción del genuino régimen mixto, y la presenta como la negación de la optima politia bene commixta imaginada por el Aquinate:

El resultado sería un "gobierno mixto" exactamente opuesto al de la "receta" de Polibio (antecedente del Aquinate): no la "óptima república", sino la "pésima república", que es peor, por suma de sus males, que cualquiera de los regímenes corruptos simples, porque reuniría en sí las perversiones de todos. Sería el peor gobierno en la medida en la que es el "gobierno de los peores", de las distintas especies recogidas y combinadas juntas casi como si fueran ingredientes, no de una receta sanadora, sino de una fórmula venenosa: de un maleficio. Si quisiéramos darle un nombre, propondría Ilamarlo kakistocracia: precisamente lo contrario de la aristocracia entendida en el sentido más amplio y noble de "gobierno de los mejores" (Bovero, 2002: 144).

Nuestro peorcrático Estado social de derecho colombiano parece mixturar, en la práctica, en un solo régimen, no los caracteres más valiosos de las mejores constituciones, sino los más deplorables y viciosos de las peores. Los colombianos podríamos pensar que no estamos solos y que tenemos modelos prestigiosos, por ejemplo, en Europa... El jurista y filósofo del derecho Luigi Ferrajoli nos confirma esta persuasión consoladora, al presentarnos el Estado italiano, convertido en tangentopoli (polis de las comisiones, fundada en la ilegalidad, en cuyo seno circulan todas las formas de corrupción); su funcionamiento, sorprendentemente, se parece mucho al de nuestro presidencialismo patrio:

\begin{abstract}
Tangentopoli se ha convertido [...] en el nombre apropiado de nuestro Estado social de no-derecho y de nuestra economía corrupta, edificados en los últimos decenios gracias a la apropiación de las instituciones por parte de los partidos, a la fuerte y difusa radicación social de la corrupción, a la ausencia de responsabilidad política y de recambio de la clase en el gobierno y a su sistemática impunidad e inmovilidad (Ferrajoli, 2008: 278).
\end{abstract}

También en nuestra tangentopoli nuevos "factores reales de poder" (Echeverri, 2002: 255) ${ }^{27}$, sin responsabilidad política, se apropiaron de las instituciones del régimen mixto proyectado en 1991 y que resultaba una denuncia global del aparato de intereses corrupto y corruptor tradicional. Los ingenuos y entusiastas constituyentes, de afinado sentido ético, se prometían que su Carta funcionaría como un instrumento eupédico para formar al nuevo colombiano, protagonista de la ética civil inspiradora de la futura democracia aristogénica. Pero 20 años más tarde, los ex constituyentes que quedan tienen que reconocer melancólicamente que la peorcracia se los "comió vivos". El gran texto, pues, constitución de papel, queda como propuesta de tarea pendiente (aunque más de futurible que de futuro realizable).

\subsection{Cacopedia colombiana}

Sin duda que no solamente nuestra historia -percibida en sus orígenes por fray Bartolomé de Las

27 Cf. Lassalle, Ferdinand. 
Casas como aventura sanguinaria de "insignes carniceros", movidos por el apetito del "muy mucho oro y esmeraldas" (Las Casas, 1974: 81, 109 ss.)-, sino también nuestra mentalidad acumulativoexplotadora y las prácticas educativas que la vehiculan y la fomentan, explican la permanencia de nuestra peorcracia, siempre dinamizada por la auri sacra fames (Virgilio, 1959: 3, 57) ("maldita hambre de oro"). Como el proceso educativo resulta ser el mecanismo de reproducción de las constantes históricas, parece que las costumbres pedagógicas deben considerarse uno de los factores decisivos para entender nuestro modo de ser nacional. Este modo de ser, cada vez menos viable desde el punto de vista ético, es producto de los hábitos cacopédicos en todas sus formas y niveles, a partir de la inducción dañina de la familia en disolución, marcada por las perversiones colectivas y primera reproductora de las mismas.

La cacopedia colombiana se expresa en mensajes de todo tipo, desde los consejos maternales, pasando por los modelos escolares, hasta los discursos, la publicidad, las imágenes, los eslóganes de los medios de comunicación, vehículos de todos los intereses de distinto valor en mescolanza de neutralidad axiológica. No solo hay influencia perversa de los lenguajes, sino de todos los modelos de vida, traducidos en comportamientos, actitudes, gestos, estilos, con impacto especial de los falsos paradigmas de kalokagathía (artistas, políticos, comunicadores, modelos, deportistas...) que los medios publicitan y que casi siempre esconden la primacía de la kakía... Por ello, el ideal griego se transforma en kalo-kakía (belleza física y disposición viciosa), pero más propiamente en kakía integral. Los recursos de la cacopedia son incontables: así se torna más y más eficaz para alimentar nuestras creativas formas de cacocracia, que exige inestabilidad axiológica.

Como existe interdependencia estrecha entre las aspiraciones familiares a la riqueza rápida de sus miembros y el fundamento-móvil plutocrático del régimen colombiano, la cacopedia arranca con las persuasivas y tal vez cariñosas palabras de la madre ("cucha"), la primera educadora: "Consiga plata, mijo, honradamente, pero si así no se puede, consiga plata, mijo" (Aguirre, 2004: 12). Este consejo proverbial se atribuye especialmente a las estimuladoras madres antioqueñas. El periodista Alberto Aguirre escribía hace algunos años:

Por algo fue en Antioquia donde floreció la mafia y se extendió la droga. Antioquia es la patria natal del narcotráfico. Los capos brotaron en esta región, y aquí montaron su imperio, sometiendo a su influjo al globo de la sociedad. En sus haciendas de las Mil y una Noches eran regaladas las más notables figuras de la sociedad y de la política. Las castas antioqueñas se rindieron ante el poderío económico de los mafiosos, y estos supieron convertirlo en poder político, gracias a la impudicia y avidez de dichas castas. También en Antioquia operan las mejores mulas (2004: 12).

Aguirre insiste en que la cacopedia paisa no surgió de repente. Sugiere antecedentes desde el siglo XIX: la falsificación de libras esterlinas, los contrabandos de todo tipo, el prototipo regional del tahúr desplumador, itinerante de toda feria, etc.

Llama la atención que la familia de quien presidía el régimen mixto colombiano hasta agosto del 2010 evidenciaba la marca del calvinismo antioqueño: "los elegidos deben ser ricos". Con esa idea, la influyente familia acumuló latifundios y negocios, y desde 1960 anidó en tierras del departamento de Córdoba, donde compró barata la hacienda $\mathrm{El}$ Ubérrimo $^{28}$ (tierras abundantes y fértiles), en cuyo entorno brotaron los ejércitos privados de los ricos, pues de las seguridades la más importante es la de la propiedad. Pero los ricos de El Ubérrimo no vieron nada, tal vez porque la gran extensión de la hacienda no permitía ver a simple vista los entrenamientos de Salvatore Mancuso. Había que

28 Cf. Cepeda, Iván y Rojas, Jorge, A las puertas de El Ubérrimo, Debate, Bogotá, 2009, passim. 
usar potentes binóculos. Los hijos del que presidía también se apresuraron a hacerse ricos, con respaldo de funcionarios sin escrúpulos, algunos subalternos directos de su padre "trabajador". Este, tal vez, para echarle tierra al escándalo, declaró, sin evidencias, el estado de desastre nacional por la amenaza de la endemia de influenza porcina que venía de México. Tom y Jerry, por su parte, explicaron que solamente habían continuado haciendo el "trabajo" de su familia materna, que desde hacía más de 30 años compraba barato, dejaba valorizar (ipor efecto de la "mano invisible"?) y vendía con ganancia... ¿Sería que la madre había acosado a los dos hijitos, repitiéndoles el consejo matriarcal ancestral, con énfasis en la reiteración sin condición? No sabemos...

Sorprendía mucho el esfuerzo filosofante de la ex primera dama (magistra vitae) cuando intentaba definir la idea de la dignidad, que se reducía, según ella, a la "cualidad de las personas sensibles a las ofensas (Moreno, 2009: 10-11), de los sujetos capaces de in-dignarse. Tal vez por eso, $T$ y J, denunciados por su sospechoso enriquecimiento, se in-dignaron y se apresuraron a protestar públicamente: así adquirían "dignidad". Para ella, la dignidad no es esencial a la personeidad, y se sorprendía de que una negra pudiera tenerla y dársela como "regalo" a su hijo. La ex primera dama recomendaba "devolver al dolor el lugar sagrado que le corresponde", pues en la medida en que el sufriente tiene motivos para in-dignarse y reclamar, en esa medida tiene dignidad. Tal vez porque los campesinos cordobeses y todos los desplazados sufrían en silencio y no se atrevían a in-dignarse, ella no les reconocía dignidad... Había que apretarles el dolor...
Pero es patente que la estimulación temprana ${ }^{29}$ cacopédica al futuro agente cacocrático no ocurre solamente en paisalandia, sino que se practica en todas las regiones colombianas, a todo lo largo y ancho de nuestra geografía: costeñas, vallunas, bogotanas, boyacenses, santandereanas, tolimenses, pastusas... La mayoría de madres desean que sus hijitos "consigan plata" sin condición para que sean "alguien en la vida", "exitosos", "importantes"... Y la cacopedia maternal y de los medios no sólo anima a los varones, sino también a sus hermanas: "Mijita, como sos fea, buscá plata como podás o conseguite un 'marrano' con plata viejo y cegatón... Como sos bonita, no olvidés que 'sin tetas no hay paraíso'". Esa inducción plutofílica se convierte en resorte de Ios sueños de todos y todas: militares, policiales, profesionales, comerciantes, artistas, prepagos, comunicadores, deportistas, autodefensas, guerrilleros, guaqueros, mineros y... hasta eclesiásticos (en quienes tampoco arraigan los antiguos ideales de los austeros clérigos que itineraban firmes en sus convicciones, movidos por las exigencias de su fe, y que evitaban llevar doble vida ${ }^{30}$.

29 Los psicólogos eu-pédicos insisten en iniciar la estimulación temprana durante la gestación, utilizando música de buen gusto que excite el bienestar del nascituro, para que arraiguen en él el deseo de vivir y los sentimientos positivos... En el seno de muchísimas familias colombianas, las madres comienzan la estimulación temprana para los sentimientos negativos de despecho, de desprecio por la vida, de autodestrucción..., escuchando a alto volumen géneros musicales que expresan desilusión, derrotismo, pesimismo, odio, ira, apología del delito, invitación a la vida anómica, al libre desarrollo de la personalidad (con libertad de indiferencia o de capricho)... La reiteración machacona de la Cruz de marihuana será aprestamiento para que los cachorros de Los liones de la manada, a poco tiempo de paridos, vayan gateando en busca de la kakía que los hará "felices". En adelante, los medios cacopédicos tendrán garantizado el éxito, reforzado por los perversos ejemplos de familia y de barriada.

30 Es posible que la cacopedia llegue hasta los seminarios. De ahí Ios malos ejemplos recientes: del fundador de los Legionarios, o el caso del ex obispo semental del Paraguay, quien explica su caso por determinismo cultural. ¡Tal vez porque, a raíz de la guerra de la Triple Alianza en el siglo XIX, el Paraguay perdió casi toda su población masculina!... Y el caso del cura narcisista de la televisión (del programa Hablando claro) que, para evitar cumplir "reglas imposibles", cambia de iglesia como el cangrejo ermitaño cambia de morada: le da lo mismo una lata de cerveza que un zapato viejo... Escogió la rama norteamericana de la iglesia organizada por el rey Enrique VIII, quien precisamente necesitaba darse buena conciencia. Ojalá el "padrecito" no sea tan inestable como el insaciable rey. 
Naturalmente que el consejo materno se justifica en el sentido de "conseguir plata honradamente" para alcanzar los medios de vida necesarios. El Aquinate está de acuerdo:

\begin{abstract}
Si los hombres intentaran vivir de acuerdo con la virtud, estarían contentos y satisfechos con las cosas que bastan para el sustento de la naturaleza. Pero como, dejando de lado ese intento, ansía vivir cada uno según su voluntad y capricho, de ahí que cada cual intente adquirir todo lo que le permite cumplir su voluntad; y como el deseo desordenado de los hombres tiende al infinito, por eso codician ilimitadamente las cosas que puedan satisfacer su deseo ${ }^{31}$.
\end{abstract}

Los servidores públicos, por ejemplo -ricos, acomodados, pobres, codiciosos, "no virtuosos" -32 , con mentalidad atizada por el clima cacopédico nacional, no están contentos con sus "suelditos" que les permiten adquirir las cosas que les bastan para el sustento de la naturaleza, e intentan adquirir todo lo que les permite cumplir su voluntad. Por ello, al acceder a sus puestos -inspirados por sus imaginarios de origen rural- perciben al Estado como una gran finca pastoril y frutera, que no pertenece a nadie, a donde se llega con "uñas libres" a ganadear y cosechar. Sueñan casi todos con disponer (apropiarse, usar, desviar) del "ganado" (pecus = metáfora del erario público) y con "sacudir" (concútere) cuanto árbol esté fruteciendo. No importa si el Código Penal, en el título $\mathrm{XV}$, reprime casi todas las formas de robar o desviar el "ganado" público o las variadas formas de "sacudir", que no solamente se quedan en la concusión propiamente dicha, sino que abarcan el cohecho, la celebración indebida de contratos, el tráfico de influencias, la mayor parte de los tipos delictivos contra la Administración Pública. Los

31 Com. a la Pol. L. I, lect. 8.

32 Los abuelos o los padres ejemplares le proponen a su hijo, como timbre de orgullo, mantenerse "pobre, pero honrado", lo cual significa que en Colombia "pobre" no implica honradez. Esta es una virtud poco frecuente entre pobres. De la pobreza como tal no se presume la honradez, sino lo contrario. depredadores no se asustan, pues saben que hay que "hacerlo bien", y que los alcanzados por el brazo débil de la cegatona justicia son solamente los "cascareros" confiados. Si cae algún pez gordo, este cuenta con la posibilidad de denunciar a sus juzgadores por conductas idénticas.

A la inducción plutomaníaca familiar se agregan los refuerzos de los siguientes niveles cacopédicos, hasta el tope de la "cacopedia superior", que puede proporcionar las metas y los instrumentos más adecuados para el ejercicio caco-profesional. Muchos profesionales se dedican a explotar la ignorancia ajena (de la medicina, del derecho, de la arquitectura, de la economía...). A los educandos se les insiste en la importancia vital de la autoestima desafiante (veneración del ego); en que se preparen para no ser perdedores, sino para el triunfo, para ser competidores o competitivos (antes que competentes y útiles). Sin aclarar acerca de los valores a que hay que apuntar para calificar el triunfo, la competición o el talante combativo ante los desafíos... Sobre-salir, en el sentido de "poner la pata a los demás", es la expectativa del clan, favorecida por el imaginario doméstico hasta en los contrapicados de las fotos de los álbumes familiares, donde algunos héroes y heroínas de uno $u$ otro apellido miran desde arriba. A ellos $y$ a ellas se les insiste en que deben ser guerreros, "echaos pa' lante", no importa si pertenecen al ejército de Sauron o al de Gondor, en el Señor de los Anillos (Tolkien, 2007). De ahí que no sean rareza las tipologías DMG, T. y J., los traquetos, los sicarios y las prematuras vocaciones de "animal político" (¿político animal?), ambicioso y agresivo... Por eso, nuestra sociedad se va convirtiendo en la zoociedad rugiente que denunciaba Garzón, y que le costó la vida.

Por esa temprana y eficaz inducción a la arrogancia depredadora, los jóvenes hacen a un lado al prójimo y la responsabilidad, y se lanzan, "sin agüero", a toda forma de artería, de abuso o de violencia. Y si toman las armas (en las fuerzas 
armadas del régimen, o contra el régimen, o en pandillas de bacrim, antiguas autodefensas) no necesitan sino tener objetos de odio para encauzar sus impulsos. No hay que olvidar que unos y otros pueden cruzar fácilmente cualquier frontera, porque su adiestramiento cacopédico apunta a lo mismo: hacerse profesionales de la muerte (con sofisticadas armas, buena puntería y una oración oportuna), y sus odios pueden redireccionarse sin dificultad, según el atractivo del botín: "iConsiga plata, mijo!".

\section{3 ¡Vamos a matar, compañeros!}

Tomás de Aquino exigía "recta intención"33 al hombre legítimamente armado (centinela del bien común), autorizado por el poder público para la defensa interna contra los malhechores o para la defensa contra enemigos externos. Recta intención significa primacía del deseo de paz, evitando el deseo de dañar, la crueldad, la ferocidad, el ánimo implacable, la codicia... Pero la cacopedia cuartelaria forma precisamente para que el soldado se sienta superior, aprenda a odiar y refuerce su ferocidad. Mientras trota fatigado, sin poder reflexivo, debe repetir a coro y rítmicamente: "Lo más parecido al ser humano es el civil", "el camuflado se lava con sangre", "guerrillero mataré y su sangre beberé". Amén de que, cuando se lleva a los troperos a disolver motines, antes de bajar de los camiones, se los exacerba con chuzones, golpes e improperios, para que su rabia los lance como perros de presa contra los desarmados civiles que protestan...

Por otra parte, para lograr los automatismos de la obediencia ciega -"in-discreta", como la denominaba el Aquinate ${ }^{34}$ para referirse a la sumisión sin

33 ST, II-II, 40, 1.

34 ST, II-II, 104, 5, 3m. La obediencia "in-discreta" de los criminales nazis maduró en la "obediencia preventiva" de Rudolf Hoss, el jefe de Auschwitz: se obedece todo, sin discernir bueno ni malo, y, siguiendo la lógica integral del mandato perverso, el obediente adivina órdenes no dadas y se adelanta a cumplirlas. La "obediencia preventiva", fruto de la "in-discreta", no fue solamente discernimiento de objetos y fines-, se los robotiza mediante los movimientos fragmentadores de la unidad somática, en la disciplina del orden cerrado (Foucault, 1981: 139-174). Consignas y prácticas cacopédicas análogas o peores deben ser las de las fuerzas fuera de la ley. Finalmente, unos y otros resultan intercambiables, pues son meras máquinas de muerte neutras (así griten "por Dios y por la Patria"), todos sintonizados en la misma terrible consigna: "iVamos a matar, vamos a matar, compañeros!", como salmodiaban con música de Morricone los guerrilleros del filme famoso de los años $70^{35}$.

La cacopedia como instrumento de cacocracia se potencia cuando los hombres públicos, las familias públicas y los destacados plutócratas fusionan sus intereses con los de la peorcracia delictiva, que llegaba como "Pedro por su casa" hasta el mismo Palacio de quien presidía nuestro régimen mixto. Parece que la mixtura del régimen colombiano ha permitido todo tipo de mezclas en los nueve órganos (mayores y menores) de la potestas: legislativa, ejecutiva, judicial, Ministerio Público, control fiscal, Consejo Nacional Electoral, Registraduría Nacional, administración seccional, administración local. El ciudadano decente, de lábil virtud, acuciado por sus necesidades, vive perpetuamente tentado a "dar el paso" a la zona obscura donde los de arriba interactúan más allá del bien y del mal. Si ellos, tan importantes y tan "decentes", violan todas las reglas impunemente, ¿por qué yo no? Recuerda Tomás, comentando a San Agustín, que la felicidad del delincuente se nutre de la impunidad penal y

asunto de nazis. Fue práctica argentina, chilena, uruguaya... Y es práctica colombiana de las AUC, FARC, ELN, Policía, Ejército... Los falsos positivos son frutos de la misma calidad obediencial. Lo mismo vale para quien se adelanta a matar al "malo" y le lleva una prueba al gobernante (por ejemplo, una mano)... Lo mismo vale para muchas prácticas del paradigma del "derecho penal de enemigo": se aplican al delincuente principios de la guerra "en caliente", al margen de los principios del derecho penal del Estado de derecho.

35 ¡Vamos a matar, compañeros!, composición musical de Ennio Morricone para el filme del mismo nombre, dirigido por Sergio Corbucci, 1970. La intención del filme era humorística, pero el humor colombiano toma la invitación en serio. 
esta hace fuerte la mala voluntad. El delito exitoso del poderoso se torna ejemplar y cohonesta toda inconducta ${ }^{36}$.

La peorcracia, que favorece las penas irrisorias a los peores asesinos (extraditados para protegerlos de los justos reclamos de sus víctimas, o enviados como agentes de paz) y las prácticas de numerosos falsos positivos (crímenes de Estado, mal llamados ejecuciones extrajudiciales ${ }^{37}$ ), institucionalizados desde los altos niveles del mando militar y policial; la buena conciencia de los asesinos uniformados que alegan obediencia debida; el cinismo de la plutocracia parlamentaria (más bien paramilitaria); la debilidad o la incuria de los fiscales y jueces; los obscuros compromisos de todos los poderes; la apología del delito directa de las narco-novelas, y la indirecta del Código de Infancia y Adolescencia”, que, por presumir el angelismo de niños y jóvenes, favorece el sicariato y muchos otros delitos. Todo eso hace pensar en que no hay diferencia entre bueno y malo o que lo malo no es tan malo. Lo que denunciaba Hannah Arendt cuando cubría el juicio de Eichmann en Jerusalén: "la banalidad del mal" (Arendt, 2005).

La banalidad del mal, alma de la peorcracia, que integra todos los vicios públicos y privados, permite que esta se torne proteica y pueda metamorfosearse en cualquiera otra alternativa negativa, pues "abyssus abyssum invocat": plutocracia $\rightarrow$ cacocracia $\rightarrow$ coca-cracia $\rightarrow$ cacocontratación-pública $\rightarrow$ aucracia $\rightarrow$ bacrim-cracia... Ocurre como con los grandes vicios, de los que se habló atrás, que se reclaman unos a otros o

$36 \mathrm{ST}, \mathrm{II}-\mathrm{II}, 40,1,2 \mathrm{~m}$.

37 El body count (conteo de bajas), acostumbrado por los gringos en Vietnam, inspiró a nuestros militares, que, en los últimos 20 años, trataron de convencer a la opinión pública de que iban ganando la guerra, porque podían mostrar cuerpos de enemigos (bajas efectivas o positivos), que después se supo no eran tales, sino cuerpos de jóvenes engañados o de vagos urbanos, es decir, falsos positivos. Así, nuestros uniformados ganaron por años ascensos, dinero, cursos, condecoraciones, licencias... Los falsos positivos no pueden denominarse ejecuciones extrajudiciales, como pretende el joven senador Galán, porque en Colombia no puede haber ejecución judicial. uno cualquiera funciona como síntesis de los demás, en cuyo seno llevan una existencia latente o larvada. Se trata, pues, de un gran monstruo que acumula dentro de sí todas las posibilidades de degradación. Conociendo los principios que dan sentido a la existencia de nuestro Leviatán, ninguna metamorfosis posterior, por insólita que parezca, puede pensarse como alternativa de cambio. El sistema, corrompido de arriba abajo, no puede cambiarse parcialmente. Cualquier novedad, en apariencia positiva, es pronto corrompida por la dinámica del todo. Si las FARC o el ELN pretenden el cambio del sistema, dada la cacopedia que ha formado a sus miembros, una vez en el poder echarán a andar una nueva peorcracia, posiblemente peor que la anterior, si es que puede haber peor de lo peor.

Tomás de Aquino recordaba la angustia de la viejita de Siracusa al saber que se pretendía derrocar al tirano de su tiempo ${ }^{38}$, pues ella tenía experiencia de sustituciones tiránicas anteriores: los héroes "liberadores" se convertían en peores tiranos que los precedentes, pues, de hecho, el sistema plutofílico vigente engullía a los revolucionarios y los convertía fácilmente en sanguijuelas con mayor capacidad de succión. La desconfianza tomasiana por fundar el régimen en la búsqueda de riqueza se parece mucho a la desconfianza de los de Gondor frente al poder del Anillo. Tolkien trae esta consideración del sabio elfo Elrond, personaje notable de El Señor de los Anillos:

-Ay, no. No podemos utilizar el Anillo Soberano... Basta desear el Anillo para que el corazón se corrompa... Si cualquiera de los Sabios derrocara con la ayuda del Anillo al Señor de Mordor, empleando las mismas artes que él, terminaría instalándose en el trono de Sauron, y un nuevo Señor Oscuro aparecería en la tierra. Y esta es la razón por la que el Anillo tiene que ser destruido; en tanto esté en el mundo será un peligro aun para los Sabios. Pues nada es malo

38 Cf. De regno, L. I, cap. VI, núm. 18. 
en un principio... (Tolkien, 2007: vol. 1, 375-376).

De la banalidad del mal hablan también otros hechos: la costumbre gubernamental de pagar sumas de dinero con cargo al erario público (seguridad democrática) como retribución por homicidios en delincuentes o en miembros de grupos al margen de la ley, lo cual ha convencido a muchos particulares de estar facultados para "aplicar" impunemente la pena de muerte, excluida de la Constitución Nacional. De ahí los volantes de 2009$2010^{39}$ en Bogotá y en pueblos cercanos, repartidos por justicieros privados, a quienes la policía "no veía": "Llegó la hora de la limpieza social... Ya los tenemos identificados... Ya tenemos una lista de barrido inicial". Y es paradójico que las hojas se entregaron como circulares para la eupedia familiar, a fin de que los padres "estén más con sus hijos" y para que los jóvenes "cojan juicio": "No consuma droga, estudie más y esté con sus padres, reciba sus consejos y los buenos ejemplos. Esto está podrido". Los "justicieros" de la democracia debieron recibir influencia homeopática, pues parecen estar muy imbuidos del "similia similibus curentur": se ejercerá violencia contra la violencia.

Como el fuego sería nutrido, podían caer inocentes, pero los limpiadores pedían de antemano perdón a la sociedad. Acerca de los justicieros privados, enseñaba el Aquinate: "Constituiría un peligro para la sociedad y sus dirigentes el que por una presunción individual algunos pudieran atentar contra la vida..." ${ }^{40}$. Duda: iSerían los "justicieros" organizaciones de desalmados asesinos de las AUC o de las FARC, reinsertados y condenados por crímenes de lesa humanidad, pero convertidos luego en "agentes de paz"? A raíz de sus lágrimas y su petición de perdón a una abstracta sociedad, que no tiene derecho a perdonar por las víctimas de carne y hueso, se consideraban purificados $y$

39 Circular distribuída en La Mesa (Cund.), febrero 2009.

40 De regno, L. I, cap. VI. cohonestados para continuar ahora luchando en las filas de "los buenos".

\subsection{La Universidad Santo Tomás y su compromiso eupédico}

La Universidad Santo Tomás no puede marginarse de la anterior situación para pasar a hacer parte de los que "huyen" de la peste, de los bárbaros, del lobo, a la voz de "sálvese quien pueda". No basta con que la USTA siga graduando abogados, psicólogos, contadores, ingenieros, economistas, si no se compromete con las exigencias eupédicas de su misión institucional -explicitada en el Estatuto Orgánico y en el PEI-,

[...] inspirada en el pensamiento humanista cristiano de Santo Tomás de Aquino, consistente en promover la formación integral de las personas [...] para que respondan de manera ética, creativa y crítica a las exigencias de la vida humana y a las necesidades de la sociedad y del país" (E.O., art. 7).

La dignidad de "la persona humana debe ser el principio estructural y la razón de ser del quehacer universitario" (art. 8, 60), sin exclusiones, segregaciones o sectarismos, "promoviendo la cultura de la justicia social, la convivencia pacífica y el desarrollo solidario" (art. 8, 10). Con estas convicciones, traducidas en hábitos operativos, los profesionales tomasinos no garantizan solamente las competencias del saber hacer de sus especialidades, sino las virtudes del bonus homo, como decía el Aquinate, sujeto agente de la optima politia bene commixta, capaz de hacer valer su voz y su voto con lucidez para superar nuestras acostumbradas prácticas peorcráticas.

En este año de 2011, la USTA celebra y conmemora la actuación del gran profeta dominico fray Antón de Montesinos, figura inspiradora de nuestra Facultad de Derecho, quien hace 500 años se enfrentó casi solo -como "voz clamante en el desierto" - a los representantes de la cacocracia de conquistadores y colonizadores, reivindicando sin temor 
la plenitud humana de los representantes de la nueva humanidad recién descubierta, sometidos "a tan cruel y horrible servidumbre", condenados a la aniquilación como los extraños y desechables avatares del filme de James Cameron.

Fray Antón y sus compañeros iniciaron una nueva forma de eupedia para echar las bases de nuevos regímenes eucráticos, fundados en la dignidad y la igualdad de las personas, sin exclusiones ni segregaciones. De la magna homilía de Montesinos, el 21 de diciembre de 1511, partieron las primeras escuelas para criollos, indios y mestizos, de donde surgieron los estudios generales y las primeras universidades hispanoamericanas. Siguiendo el reclamo de Montesinos, años después, fray Bartolomé de Las Casas, fray Julián Garcés y fray Bernardino de Minaya -primeros activistas de derechos humanos- persuadieron al Papa de reconocer públicamente la humanidad, la dignidad y la igualdad de los indios. Y radicalizando ese reclamo, fray Bartolomé de Las Casas escribió su De regia potestate (Las Casas, 1978) ya mencionado, donde reivindica nuevamente la necesidad del régimen mixto tomasiano, cuya base es la voluntad del pueblo (de España y de las Indias), que ha pactado con el soberano, obligado a tener en cuenta el consentimiento de sus súbditos.

La USTA no puede hacer caso omiso de esta tradición eupédica y eucrática dominicana, que es la misma herencia que le dio origen en 1580. Los educadores tomasinos, por tanto, deberán desterrar de sus vidas y de sus prácticas profesorales toda artera inducción cacopédica (de palabra, actitud o ejemplo). Los educandos tomasinos deberán convertirse en terapeutas de nuestra infecta sociedad cacocrática. Tomás de Aquino les advierte a unos y a otros que

[...] no es lo mismo ser varón bueno y ser buen ciudadano, según una política cualquiera. Pues hay algunas políticas no rectas, según las cuales alguien puede ser buen ciudadano y no ser hombre bueno; pero según la política óptima, no hay buen ciudadano que no sea inseparablemente hombre bueno ${ }^{41}$.

Así, los tomasinos no pueden resignarse a ser buenos ciudadanos neutrales, como los quiere la peorcracia de la parapolítica, de los falsos positivos (por bajas o por pseudoentregas), de las chuzadas, de los carruseles de la contratación, de los magistrados, de Agro Ingreso Seguro... de toda forma de corrupción. A la cacocracia le conviene el ciudadano indiferente, imparcial, pasivo, al que los griegos designaban con la palabra idiota. El buen ciudadano tomista debe ser al mismo tiempo hombre bueno, y esta dimensión lo obliga a ejercer una ciudadanía de resistencia, de desobediencia civil, de oposición, de lucha, de crítica, de participación constructiva, evitando toda modalidad de muda idiotez consentidora (qui tacet consentire videtur si loqui debuisset ac potuisset = "el que calla parece consentir, si debe y puede hablar"). El ciudadano resignado y adaptado a una política corrupta no puede ser buen ciudadano. Para serlo, debe superar la conformidad y comprometerse con alguna forma de subversión de las estructuras peorcráticas en nombre de la justicia y del bien común.

Por su misión, principios generales y objetivos estatutarios, la USTA continúa los ideales de los dominicos del siglo XVI y recoge el paradigma de los grandes procuradores y defensores de indios, lo que la convierte en una especie de ministerio público (central ética) educativo, obligado a actuar mediante la docencia, la investigación y la proyección social, como baluartes firmes de la dignidad de las personas, de los derechos humanos, de los valores de convivencia, de los derechos de la sociedad y del funcionamiento justo del mejor régimen político.

Hoy tenemos a un Procurador General de la Nación de formación tomasina. Démosle tiempo de hacer honor a su alma máter. Y, entre tanto,

41 Com. Eth. V, 3. 
Ios educadores USTA continuemos trabajando para alcanzar el segundo objetivo estatutario: "formar líderes con sentido crítico de la realidad y compromiso ético, para llevar a cabo los cambios necesarios en la vida social y promover el desarrollo integral de nuestro pueblo" (E.O. art. 9, $2^{\circ}$ ). El tomasino -que debe y puede hablar-, no puede convivir pasivamente con la peste de la peorcracia ${ }^{42}$ si quiere ser a un tiempo buen hombre y buen ciudadano. Albert Camus nos sugirió la metáfora de La peste para referirse a una pandemia político-social como la nuestra, sólo combatible mediante encerramiento de cuarentena. Y el buen viejo Saramago nos proporcionó dos magníficas metáforas acerca de cómo superar los males colectivos: Ensayo sobre la ceguera, cuyo relato da centralidad al liderazgo femenino, pues sólo una mujer mantiene la capacidad de ver con ecuanimidad cuando el resto ha perdido la visión y el juicio; y Ensayo sobre la lucidez, en el cual el demos que siempre votaba y elegía, al final entra todo en abstención y deja de votar y de elegir. Al atardecer todos los socios peorcráticos empiezan a huir hacia la frontera. Los líderes tomasinos deben escoger qué activar y en qué dirección; y las tomasinas deben hacerse conscientes de si tienen vista aguda para pretender ver mejor en dirección eucrática de justicia y bien común.

42 Desarticulación de la sociedad y del régimen mixto / violación sistemática de los derechos humanos / exclusión socio-económicocultural-política de millones de colombianos / desplazamiento y desarraigo masivos (2 millones, 70\% mujeres y niños) / desempleo e inestabilidad laboral / mísero-economía marginal / fuerte deterioro de la coexistencia y de la convivencia / múltiples formas de violencia / conflicto armado sostenido o guerra abierta de dos ejércitos anti-régimen versus dos ejércitos del régimen / paracracia / falsos positivos / guerra sucia y terrorismo / secuestroindustria /daño en la infraestructura y deterioro ecológico / crimen organizado y narcotráfico / pérdida del monopolio de la fuerza por parte del Estado / precariedad del Estado y paulatina ingobernabilidad / deslegitimación del Estado y de las fuerzas políticas / partidos políticos en disolución / fraude electoral consentido / modelo de desarrollo ineficaz para superar pobreza y desigualdad / privatización monopólica de bienes públicos / corrupción política y administrativa / cleptocracia rampante / debilidad del sistema de justicia / impunidad generalizada y estado de inseguridad / desprestigio internacional / desafíos de la globalización, que hacen preferir la competitividad del mercado sobre la solidaridad social...

\section{REFERENCIAS}

Abbagnano, N. (2001). Diccionario de Filosofía. México: FCE.

Aguirre, A. (2004, nov. 22). Se vende finca. En Cromos.

Agustín. (1988). Ciudad de Dios. Buenos Aires: Porrúa.

Álvarez Conde, E. (2006). Curso de derecho constitucional, t. I. Madrid: Tecnos.

Arendt, H. (2005). Eichmann en Jerusalén. BarceIona: Lumen-DeBolsillo.

Aquino, T. (1932). Summa theologica. Parisiis, Blot.

Aquino, T. (1996). Gobierno de los príncipes (De regno). México: Porrúa.

Aquino, T. (2001). Comentario a la Ética de Aristóteles. Pamplona: Eunsa.

Aquino, T. (2001). Comentario a la Política de Aristóteles. Pamplona: Eunsa.

Aquino, T. (2003). Comentario a las Sentencias de Pedro Lombardo. Pamplona: Eunsa.

Aristóteles. (2006). Protréptico. Madrid: Abada.

Aristóteles. (2006). Constitución de Atenas. Buenos Aires: Aguilar.

Bourdieu, P. (2010). El sentido práctico. Buenos Aires.

Bovero, M. (2002). Una gramática de la democracia: contra el gobierno de los peores. Madrid: Trotta.

Caro, J.I. (1974). Bonanza y tempestad. Bogotá: Kelly. 
Cicerón. (1970). República. Buenos Aires: Aguilar.

Demongeot, M. (1937). El mejor régimen político según Santo Tomás. Buenos Aires: Santa Catalina.

Echeverri Uruburu, Á. (2002). Teoría constitucional y ciencia política. $\left(6^{\mathrm{a}}\right.$. ed.). Bogotá: Librería del Profesional.

Eco, U. (1994). Segundo diario mínimo. Barcelona: Lumen.

Ferrajoli, L. (2008). Democracia y garantismo. Madrid: Trotta.

Fioravanti, M. (2001). Constitución. Madrid: Trotta.

Forment, E. (2007). Santo Tomás de Aquino [el oficio del Sabio]. Barcelona: Ariel.

Foucault, M. (1981). Los cuerpos dóciles. En Vigilar y castigar. Bogotá: Siglo XXI.

Lacordaire, H. (1998). Memoria para la restauración de la Orden de Predicadores en Francia. En Santo Domingo y su Orden. Madrid: Edibesa.

Lacordaire, H. (1998b). Vida de Santo Domingo. En Santo Domingo y su Orden. Madrid: Edibesa.

Las Casas, B. (1974). Brevísima relación de la destrucción de las Indias. Barcelona: Fontamara.

Las Casas, B. (1978). El poder de los reyes y los derechos de los súbditos. En Derechos civiles y políticos. Madrid: Ed. Nacional.

Limpieza social. (2009, febrero). Circular divulgada en La Mesa, Cundinamarca.

Mora Díaz, F. (1939). Flor de fango. En Chispas del yunque. Tunja: Ed. El Cruzado.

Moreno, L. (2009, abril). Dolor y dignidad. En revista Diners.
Morricone, E. (1970). ¡Vamos a matar, compañeros! Composición musical para el filme del mismo nombre, dirigido por Sergio Corbucci.

Ortega y Gasset, J. (1956). Historia de la filosofía de Emile Bréhier (prólogo). Buenos Aires: Ed. Sudamericana.

Platón. (1966). Las leyes. Madrid: Aguilar.

Prélot, M. (1969). Ciencia política. Buenos Aires: EUDEBA.

Stoetzer, O.C. (1981). Raíces escolásticas de la Constitución norteamericana. En revista Franciscanum, 77. Bogotá: Universidad San Buenaventura.

Tolkien, J.R.R. (2007). El señor de los anillos, (I, II y III). Barcelona: Minotauro.

Uprimny, L. (1968, ene.-abr.). Santo Tomás de Aquino y el derecho público contemporáneo. En Revista Universidad de Santo Tomás, (I) 1. Bogotá.

Virgilio, P. (s. I a. C.) (1959). Eneida. Barcelona: Ed. Vergara. 